\title{
FETAL VARIANT ANATOMY OF GREAT SAPHENOUS VEIN
}

\author{
Tatiana V. KHMARA ${ }^{1}$, Pavlina V. HRYHORIEVA ${ }^{1}$, Mariana A. RYZNYCHUK ${ }^{1}$, \\ Vira M. DRACHUK ${ }^{1}$, Galyna Ya. STELMAKH ${ }^{1}$
}

${ }^{1}$ Higher State Educational Institution of Ukraine „Bukovinian State Medical University“, Chernivtsi, Ukraine

Received 12 Febr 2020, Accepted 03 Apr 2020

https://doi.org/10.31688/ABMU.2020.55.2.01

\begin{abstract}
Introduction. The accumulated factual material about the topography of the great saphenous vein is extremely contradictory. Therefore, an individual approach is necessary to study the age-related anatomical variability of the large saphenous vein in human fetuses.
\end{abstract}

The objective of the study was to determine the peculiarities of the saphenous vein topography in human fetuses of 4-10 months.

Materials and methods. Studies of the variant anatomy of the great saphenous vein (GSV) were carried out on specimens of the lower limbs of 80 human fetuses of 81.0-375.0 mm parietal-coccygeal length using macro-microscopic dissection, vascular injection, surface staining of prepared vessels and nerves, radiography and morphometry.

Results. GSV is a continuation of the medial marginal vein, which is directed upwards in the subcutaneous tissue along the anterior edge of the inner ankle in the studied human fetuses. On the lower leg, the GSV runs along the medial edge of the tibia and receives superficial veins from the anterior medial surface of the lower leg. The GSV bends around the back of the medial epicondyle of the femur in the knee area, is located outside the sartorial muscle, and passes to the anteromedial surface of the thigh. The GSV returns

\section{Résumé}

Anatomie fotale aberrante de la veine grande saphène

Introduction. Le matériel factuel accumulé sur la topographie de la veine grande saphène est extrêmement controversé. Par conséquent, une approche individuelle de l'étude de la variabilité anatomique liée à l'âge de la veine grande saphène chez les foetus humains est nécessaire.

Le but de l'étude est de découvrir les caractéristiques de la topographie de la veine grande saphène chez les fotus humains âgé de 4-10 mois.

Matériel et méthodes. L'étude de l'anatomie variante de la veine grande saphène a été réalisée sur les préparations des extrémités inférieures de 80 foetus humains à longueur pariétale-coccygienne de 81,0-375,0 $\mathrm{mm}$,par préparation macro-microscopique, injection de vaisseaux, coloration superficielle des vaisseaux et des nerfs préparés, radiographie morphométrie.

Résultats. Dans les foetus humains étudiés, la grande veine saphène est une continuation de la veine marginale médiale qui court vers le haut dans le tissu sous-cutané le long de la marge antérieure de la malléole mediale. Sur le tibia, la veine grande saphène s'étend le long de la marge médiale du tibia et reçoit des veines superficielles de la surface antérieure médiale du tibia. 
inward through the perforated fascia. In the saphenous opening area, it bends around the lower corner of the falciform margin of the saphenous opening, and it flows into the femoral vein (FV) from the anteromedial side. The anterior accessory saphenous vein flows into the femoral part of the GSV in $45 \%$ of cases. The posterior accessory saphenous vein is formed from the saphenous veins of the medial and posterior surfaces of the thigh.

Conclusions. The anatomical variability of the great saphenous vein has been determined in human fetuses. The anterior accessory saphenous vein was detected in $71.3 \%$ of the studied fetuses, while the posterior accessory saphenous vein was found in $38.1 \%$ of cases. The great saphenous vein is characterized by the predominance of the transitional vein type $55.6 \%$ of cases) over the main (33.8\% of cases) and loose (10.6\%o cases) ones. The main type prevails over the loose type in the ratio of 3.2:1. The coincidence of the type of formation of a great saphenous vein on the right and left lower extremities was observed in $61.3 \%$ of fetuses. Significant gender differences in the typology of the great saphenous vein in human fetuses were not found.

Keywords: great saphenous vein, anatomical variability, topography, fetus, human.

\section{INTRODUCTION}

The varicose disease of the lower extremities is a common disease that occurs, according to various authors ${ }^{1,2}$, in $17-51.4 \%$ of the population in developed countries, including in $12-50 \%$ of working-age population ${ }^{3}$. Isolation of the great saphenous vein (GSV) and its branches at varix dilatation, as well as the hernial sac with recurrent femoral hernias in people with obesity, sometimes cause considerable difficulties and can lead to damage to the femoral vein (FV). Especially dangerous is the separation of GSV at the point of its confluence with the FV. In these cases, the bleeding may be significant. In some patients, due to the atypical location of the venous collector, the common FV trunk may be mistaken for GSV and crossed. FV passage-way is successfully restored using a circular atraumatic suture ${ }^{4}$ in such cases.

Damage to the main veins of the pelvis and lower extremities during various surgical interventions is a dangerous and severe complication that requires
Dans la région du genou, la veine grande saphène recourbe vers le condyle médial du fémur, s'étend de l'extérieur du muscle sartorius et se déplace vers la surface antérieure médiale de la cuisse. Dans le domaine de l'ouverture saphène, la veine grande saphène revient profondément à travers le fascia cribriformis, contourne la corne inférieure de la marge falciforme de l'ouverture saphène et pénètre dans la veine fémorale sur sa face antérieure médiale. Dans $45 \%$ des cas, la veine saphène supplémentaire antérieure tombe dans la partie fémorale de la veine grande saphène. La veine saphène supplémentaire postérieure est formée des veines saphène des surfaces médiale et postérieure de la cuisse.

Conclusions. La variabilité anatomique d'une veine grande saphène est établie chez le foetus humain. Dans $71,3 \%$ des foetus étudiés, une veine saphène supplémentaire antérieure a été détectée et dans 38,1\% des cas, une veine saphène supplémentaire postérieure a été trouvée. La veine grande saphène est caractérisée par la prédominance du type veineux de transition $(55,6 \%)$ sur le type magistral $(33,8 \%$ des observations) et le placeur $(10,6 \%)$. Le type magistral surpasse le rapport de 3,2: 1. La coïncidence du type de formation de la veine grande saphène aux membres inférieurs droit et gauche a été observée chez $61,3 \%$ des foetus. Des différences significatives entre les sexes dans la typologie de la veine grande saphène chez les fotus humains n’ont pas été identifiées.

Mots-clés: veine grande saphène, variabilité anatomique, topographie, foetus, humain.

an immediate decision. Confusion of the surgeon in such a critical situation, ignorance of possible anatomical options and ways to stop bleeding can lead in some cases to the death of the patient during surgery. FVs are damaged relatively often during surgery, mainly in the area of GSV and FV fusion, which is primarily due to the complexity of the topographic and anatomical relationships of vessels in the Scarpa's triangle. Injury of the femoral veins can occur during the following surgical interventions: removal of superficial varicose, herniotomy of a restrained femoral hernia, removal of large soft tissue tumors and sequestrectomy for hip osteomyelitis, etc. ${ }^{5}$

Variant anatomy of the venous system of the lower extremities is very variable ${ }^{6}$. The superficial and deep venous systems of the lower extremities are connected using saphenous-femoral and saphenous-popliteal compounds and perforating veins. Three cases were described when veins from the deep vein system flowed into the great superficial vein - GSV or its proximal branch - anterior accessory saphenous vein 
(AASV) ${ }^{7}$. Accurate knowledge of the GSV anatomical variants and its branches, as well as the sites of the saphenofemoral junction, determines the successful outcome of the operation ${ }^{8}$.

GSV is often used as a blood vessel graft ${ }^{9}$. GSV isolation is an important and integral stage of coronary bypass surgery, which is of great importance for the treatment of patients with ischemic heart disease $^{10}$.

The anatomical prerequisites for the development of erectile dysfunction of venous genesis is a significant lengthening of the legs of the penis, as well as the absence of deep dorsal veins of the penis while expanding the superficial dorsal vein of the penis that flows into the GSV and ensures the outflow of venous blood from the penis ${ }^{11}$.

Recently, there has been increasing interest in studying the topographical and anatomical features of the lower extremity veins during human ontogeny various periods, due to requests for vascular surgery and ultrasound diagnoses ${ }^{12}$. As some researchers note $^{13,14}$, when the reduction of primary veins on the anterior surface of the thigh is delayed, the saphenous veins form a network with large loops, and it is rather difficult to differentiate the GSV main trunk. The latter can be represented by 2 or even 3 trunks. At the same time, the GSV trunk is often doubled in the lower third of the thigh. Independent GSV trunks usually merge into a single trunk before flowing into the FV in the upper third of the femur. The separate confluence of GSV trunks occurs relatively rarely. Branches of the main GSV trunks are connected by numerous anastomoses.

The accumulated factual material about the topography of the superficial veins of the lower extremities is extremely contradictory. Therefore, an individual approach to the study of their age-related anatomical variability, and especially, GSV, is necessary. There are no data on the most clinically significant variants of GSV in human fetuses in the literature available to us.

The obJective OF The Study was to determine the peculiarities of GSV topography in human fetuses of 4-10 months.

\section{Materials AND Methods}

Studies of the variant anatomy of the GSV were carried out on specimens of the lower extremities of 80 human fetuses of $81.0-375.0 \mathrm{~mm}$ of parietal-coccygeal length (PCL) using macro-microscopic dissection, vascular injection, surface staining of prepared vessels and nerves, radiography and morphometry.
Fetus specimens weighing more than $500.0 \mathrm{~g}$ were studied in the Chernivtsi Oblast Children's Morbid Anatomy Department, Ukraine, under a cooperation agreement. Fetus specimens taken from the museum of the M.H. Turkevych Department of Human Anatomy and the Department of Histology, Cytology and Embryology at SHEI of Ukraine Bukovinian State Medical University were also used for the study.

The study is part of the research of the Department of Histology, Cytology and Embryology at SHEI of Ukraine Bukovinian State Medical University „Regularities of Morphogenesis and Structural and Functional Peculiarities of Tissues and Organs in Human Ontogenesis", state registration No. 0116 U002938.

The study was performed in compliance with the basic provisions of the bioethics of the Council of Europe Convention on Human Rights and Biomedicine (April 4, 1997), the Helsinki Declaration of the World Medical Association on ethical principles for the conduct of medical research involving humans (1964-2013), MoH of Ukraine order No.690 of September 23, 2009, and recommendations of Ministry of Health of Ukraine „On the Procedure for Removal of Biological Objects From the Dead, Whose Bodies Are Subject to Forensic Examination and Postmortem Study, for Research Objectives" (2018). The Commission on biomedical ethics of the SHEI Bukovinian State Medical University found no violations of moral and legal norms during the research.

\section{Results AND discussion}

The GSV is a continuation of the medial marginal vein in the studied human fetuses. The GSV goes upwards in the subcutaneous tissue along the anterior edge of the medial malleolus. On the lower leg, the GSV runs along the medial edge of the tibia and receives superficial veins from the anterior medial surface of the lower leg. The GSV bends around the back of the medial epicondyle of the femur in the knee area, is located outside the sartorial muscle, and passes to the anteromedial surface of the thigh. The GSV returns inward through the perforated fascia. In the saphenous opening area, it bends around the lower corner of the falciform margin of the saphenous opening and flows into the FV from the anteromedial side. The femoral part of GSV was represented by a single trunk in $14.4 \%$ of cases ( 23 specimens); large branches were not detected (Fig. 1, 2).

The anterior accessory saphenous vein (AASV), which begins from the venous network of the anterolateral surface of the lower third of the thigh, flows 


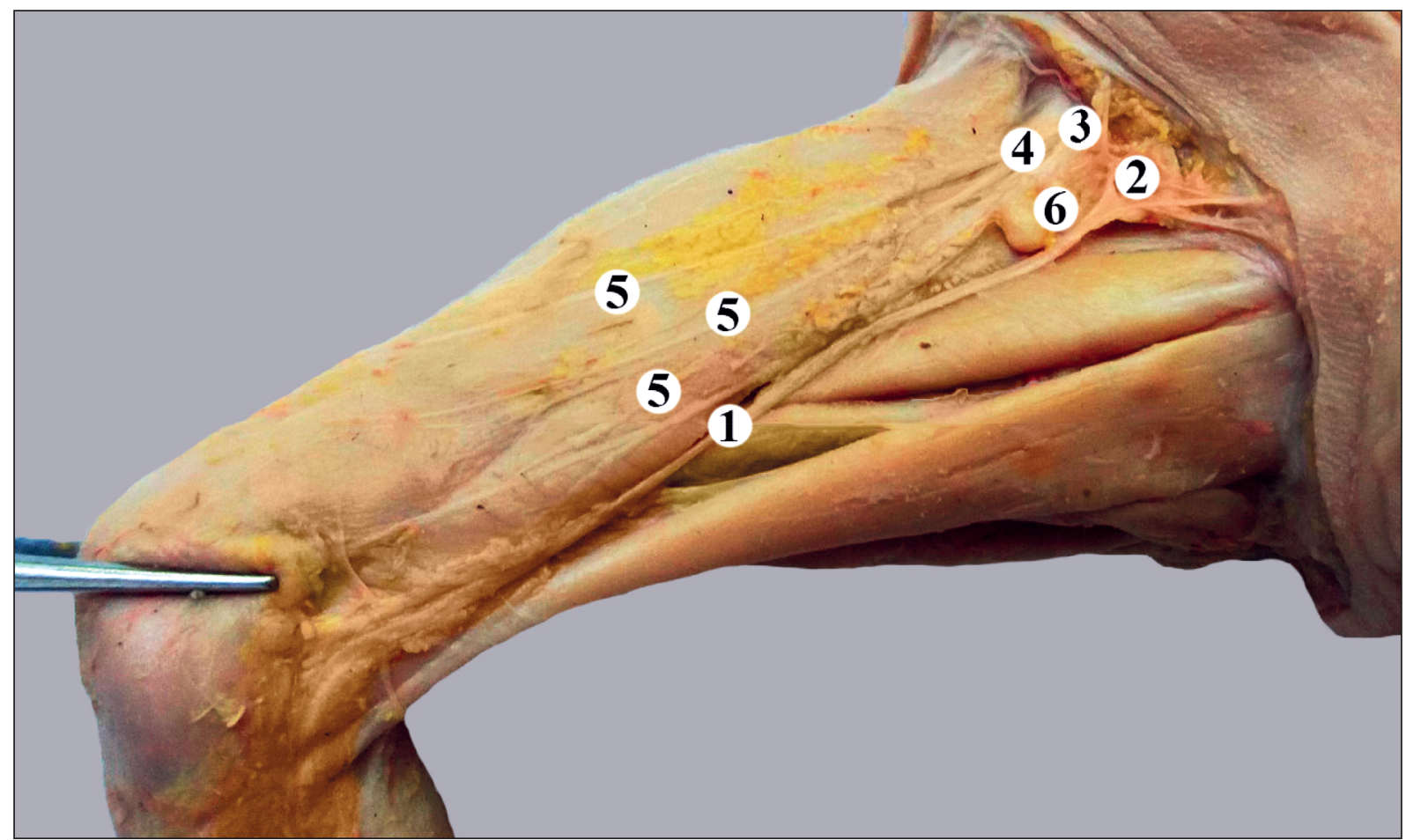

Fig. 1. Vessels and nerves of the right anterior femoral part of the male fetus - $165.0 \mathrm{~mm}$ of PCL. Gross specimen. Mag. 2.1 1 - great saphenous vein; 2 - femoral vein; 3 - femoral artery; 4 - femoral nerve; 5 - muscular branches of the femoral nerve; 6 - superficial axillary lymph node.

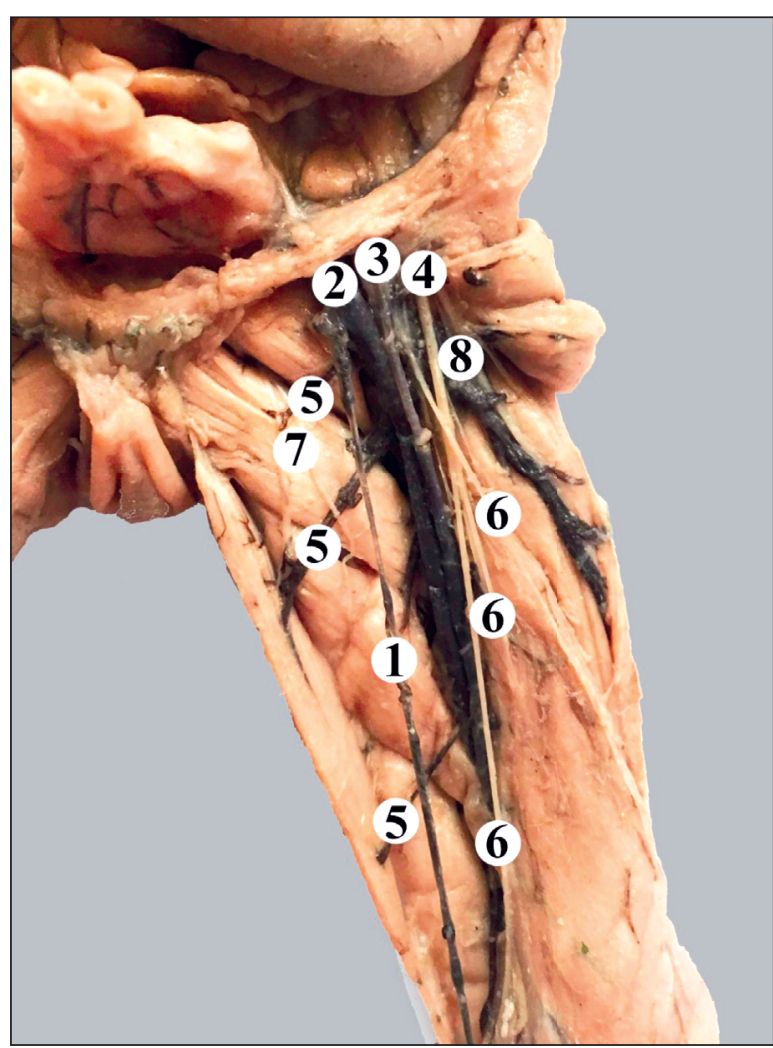

Fig. 2. Vessels and nerves of the left anterior femoral part of the female fetus $-170.0 \mathrm{~mm}$ of PCL. Gross specimen. Mag. 2.4x:

1 - great saphenous vein; 2 - femoral vein; 3 - femoral artery;

4 - femoral nerve; 5 - muscular branches of the femoral artery; 6 - muscular branches of the femoral nerve;

7 - obturator nerve; 8 - deep femoral artery.

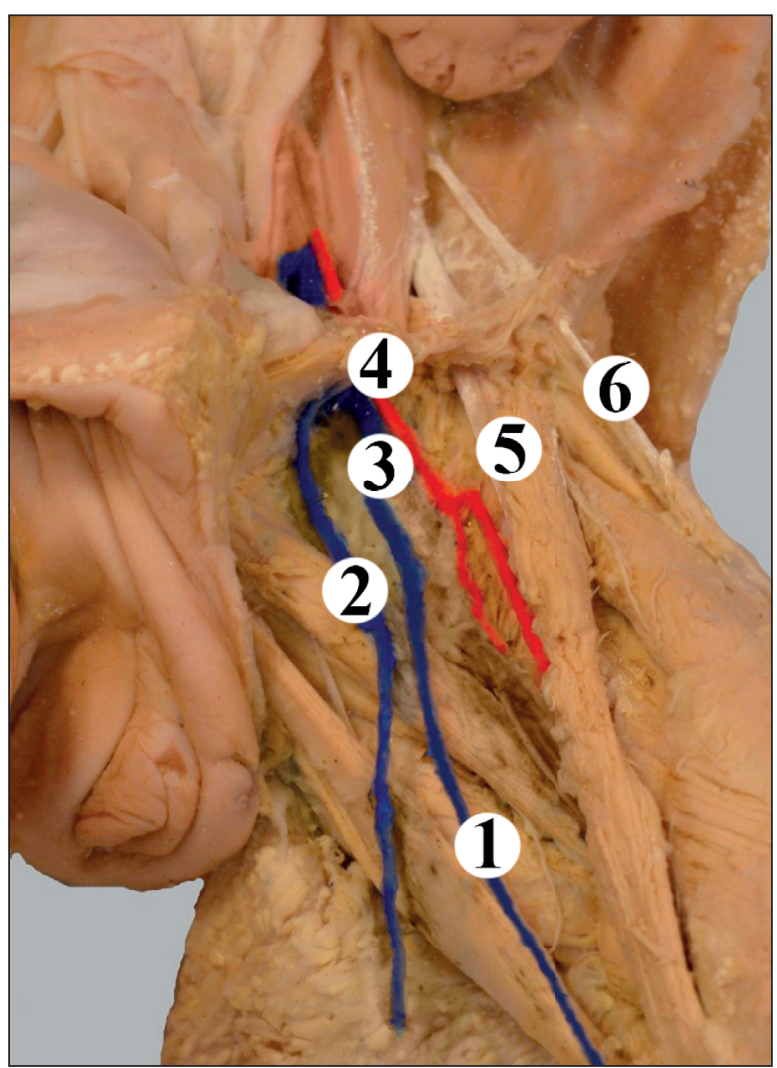

Fig. 3. Vessels and nerves of the left anterior femoral part of the female fetus $-275,0 \mathrm{~mm}$ of PCL. Gross specimen. Mag. 1.3:

1 - great saphenous vein; 2 - posterior accessory saphenous vein; 3 - femoral vein; 4 - femoral artery; 5 - femoral nerve; 6 - lateral cutaneous nerve of the thigh. 


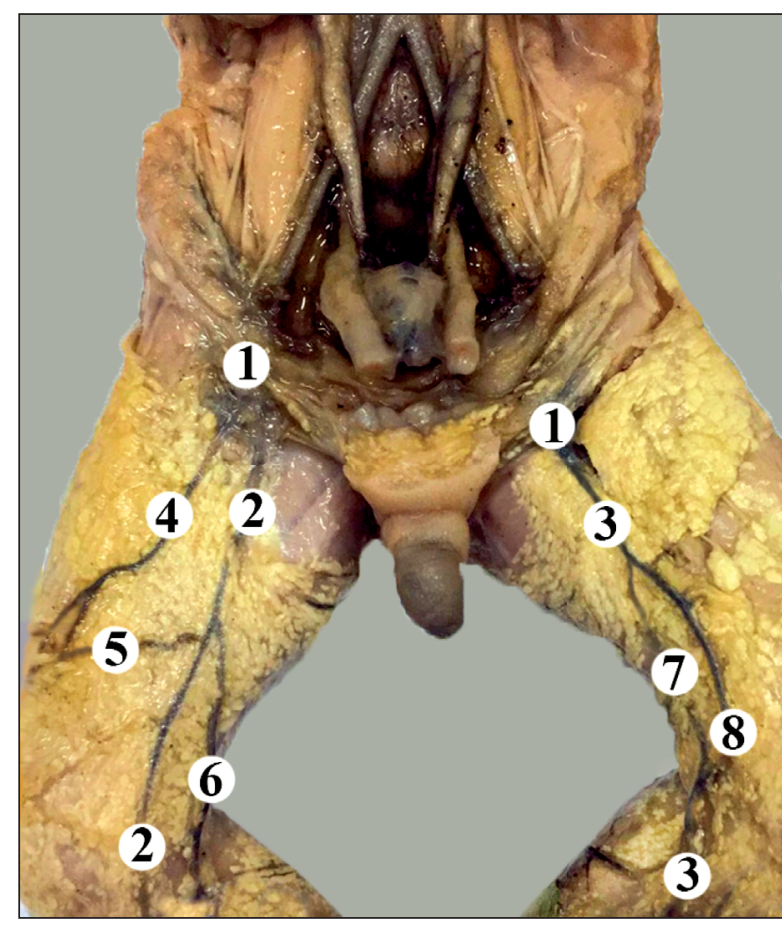

Fig. 4. Superficial veins of the right and left anterior femoral areas of the male fetus $150.0 \mathrm{~mm}$ of PCL. Gross specimen. Mag. 2.1 ${ }^{\mathrm{x}}$ :

1 - femoral vein; 2 - right great saphenous vein; 3 - left great saphenous vein; 4 - right front accessory saphenous vein; 5 - venous anastomosis; 6 - right posterior accessory saphenous vein; 7 - medial branch of the left great saphenous vein; 8 - lateral branch of the great saphenous vein.

into the femoral part of the GSV (part of the femoral triangle) in $45 \%$ of cases (72 specimens). The AASV flows into the GSV arc in $8.8 \%$ of cases (14 specimens), in $13.1 \%$ (21 specimens) - into the FV below the GSV arc and in 4.4\% (7 specimens) - into the FV above the GSV arc. There is no AASV on 46 specimens ( $28.7 \%$ of cases).

We found the posterior accessory saphenous vein (PASV) in 61 specimens (38.1\% of cases). The PASV is formed from the saphenous veins of the medial and posterior surfaces of the thigh and runs parallel and somewhat posterior to the GSV and, as a rule, flows into the latter. In the fetus, $275.0 \mathrm{~mm}$ of PCL, the left PASV collects blood from the skin and subcutaneous tissue of the medial thigh part, returns medially at the level of the inguinal ligament and flows into the left FV, above the place where it enters the last GSV (Fig. 3). The distal end of PASV anastomoses with a small saphenous vein in $13.1 \%$ of cases. The perforator veins of the middle surface of the lower leg flow into the PASV.

Atypical topography of the right and left GSV was found in the fetus of $150.0 \mathrm{~mm}$ of PCL. The right PASV begins with 2 branches - lateral and medial, from the venous grid of the anterolateral

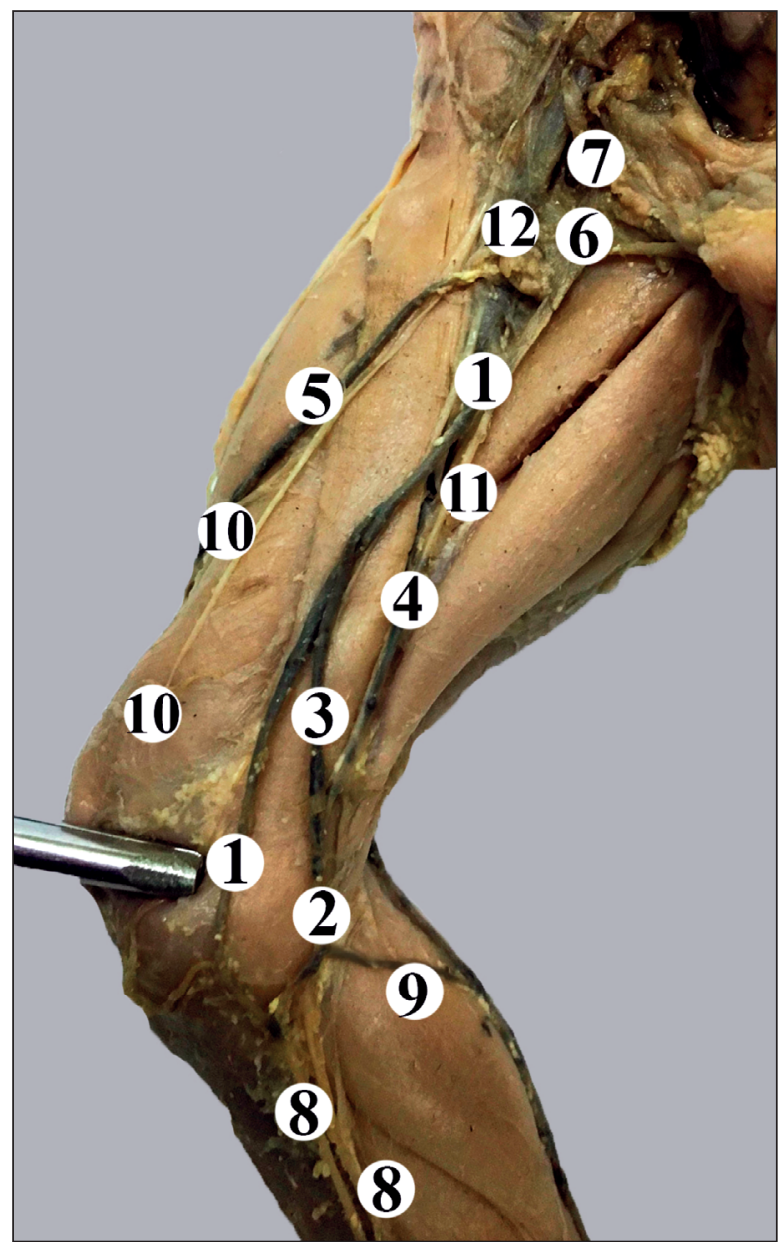

Fig. 5. Vessels and nerves of the right anterior femoral part of the male fetus $-205,0 \mathrm{~mm}$ of PCL.

Gross specimen. Mag. 2.4x:

1 - great saphenous vein; 2 - posterior accessory saphenous vein; 3 - lateral posterior accessory saphenous vein; 4 - posterior accessory saphenous vein; 5 - anterior accessory saphenous vein; 6 - arch of the great saphenous femoral vein; 7 - femoral vein; 8 - perforator veins of the lower leg; 9 - anastomosis with a small saphenous vein; 10 - muscular branches of the femoral nerve; 11 - saphenous nerve; 12 - superficial axillary lymph node.

surface of the thigh, on the edge of its middle and upper third. The right PASV in the upper third of the anterior femoral section runs almost parallel to the main trunk of the right GSV and flows into the right FV above the right GSV arc. Venous anastomosis was detected in the section of the middle third of the right anterior femoral section between the medial branch of the right PASV and the right GSV trunk. $2.0 \mathrm{~mm}$ above the latter, the right PASV flows into the right GSV (Fig. 4). The left GSV trunk in the area of the medial epicondyle of the femur is first bifurcated into the medial and lateral branches, following parallel to each other along the entire length of the anterior-medial section of the left anterior femur. $7.0 \mathrm{~mm}$ caudal to the left inguinal ligament of the medial and lateral branches of the left GSV are 


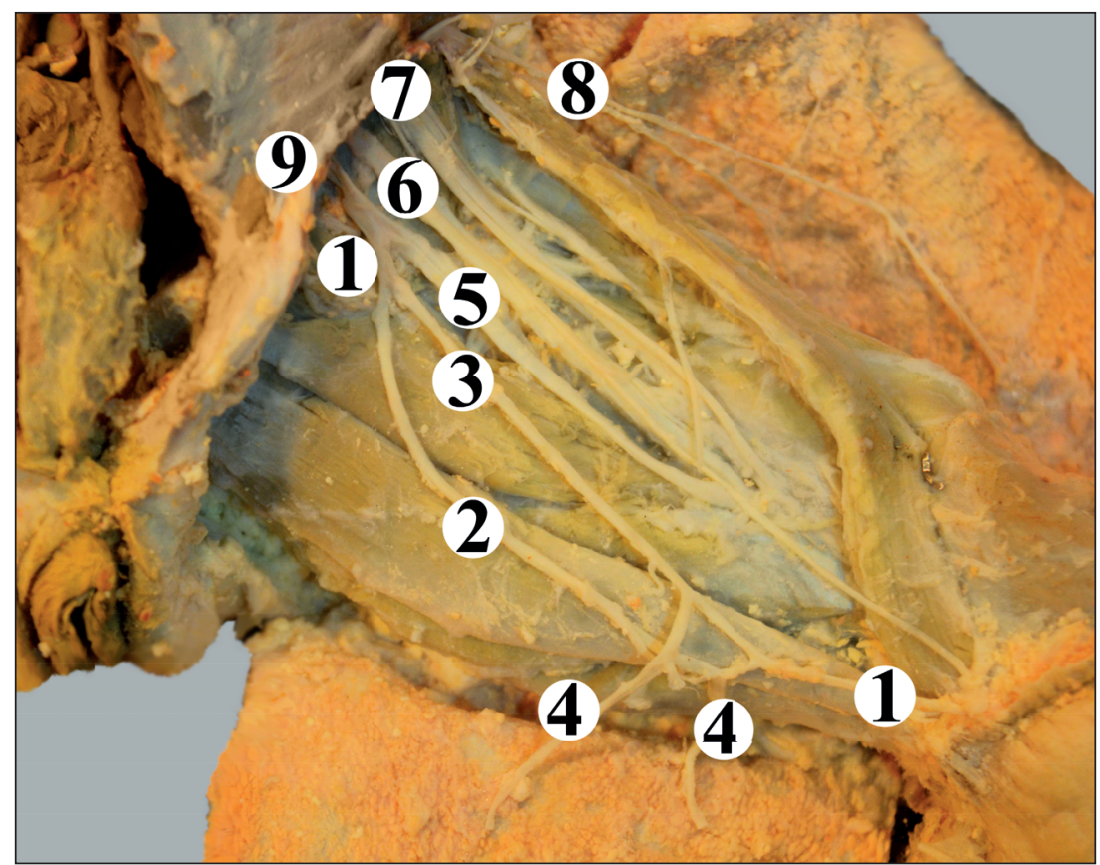

Fig. 6. Vessels and nerves of the left anterior femoral part of the female fetus $-300,0 \mathrm{~mm}$ of PCL. Gross specimen. Mag. 2.6x:

1 - great saphenous vein; 2 - the medial trunk of the great saphenous vein; 3 -the lateral trunk of the great saphenous vein; 4 - saphenous veins of the medial part of the thigh; 5 - femoral vein;

6 - femoral artery; 7 - femoral nerve; 8 - lateral cutaneous nerve of the thigh; 9 -inguinal ligament.

connected into one short trunk, $3.0 \mathrm{~mm}$ long, which flows into the left FV.

The PASV trunk is placed in the fetus $205.0 \mathrm{~mm}$ of PCL in the right knee region, medial from the main GSV trunk. The perforator veins of the middle surface of the lower leg flow into the latter. The PASV distal end forms an anastomosis with a small saphenous vein. The PASV trunk is directed upwards and at the level of the medial edge of the distal part of the sartorius muscle, it splits into 2 veins: the medial and lateral PASV. The lateral PASV goes obliquely upward, is located on the anterior surface of the sartorius muscle and flows into the GSV in the lower third of the thigh. The medial PASV goes up to the top parallel to the GSV and it also flows into the GSV on the edge of the upper and middle thirds of the thigh. The AASV goes obliquely in the craniomedial direction, bends around the superficial inguinal lymph node from above and flows into the FV below the GSV arc. The GSV returns inward through the perforated fascia in the saphenous opening area, bends around the lower corner of the falciform margin of the saphenous opening and flows into the FV (Fig. 5).

In the fetus, $305.0 \mathrm{~mm}$ of PCL the GSV in the femoral triangle section splits into two venous trunks: the medial and lateral that are connected to one common short venous trunk before flowing into the FV (Fig. 6). Saphenous veins flow into the medial and lateral trunks of the GSV collecting blood from the skin and subcutaneous tissue of the medial part of the thigh.

1-3 external pudendal veins, superficial circumflex iliac vein, superficial epigastric vein, superficial dorsal veins of clitoris (penis), anterior scrotal veins, saphenous veins of the external genitalia and anterior abdominal walls flow into the GSV in the saphenous opening area before it enters the FV (Fig. 7). We found the latter in 34 (21.3\%) specimens. Venous homocladic anastomosis between GSV branches, namely anterior scrotal veins and external pudendal veins, were detected in fetuses (Fig. 8). At the same time, we observed the inflow of the saphenous veins of pudenda and the anterior abdominal wall into GSV on 23 $(67.6 \%)$ specimens. In $14.7 \%$ of cases (5 specimens), inflows of the pudenda saphenous and anterior abdominal wall were found in the FV above the GSV arch; in $5.9 \%$ of cases ( 2 specimens), they were found in the saphenofemoral angle located posterior to the GSV and in $11.8 \%$ of cases (4 specimens) - in the PASV or AASV penetrating the wide fascia, which, in our opinion, makes it difficult to identify the place of inflow.

When studying the anatomical variability of GSV in human fetuses, we revealed the variability of the topography and the bilateral asymmetry of its branches. The variety of GSV topography variants within the anterior femoral area in human fetuses, 


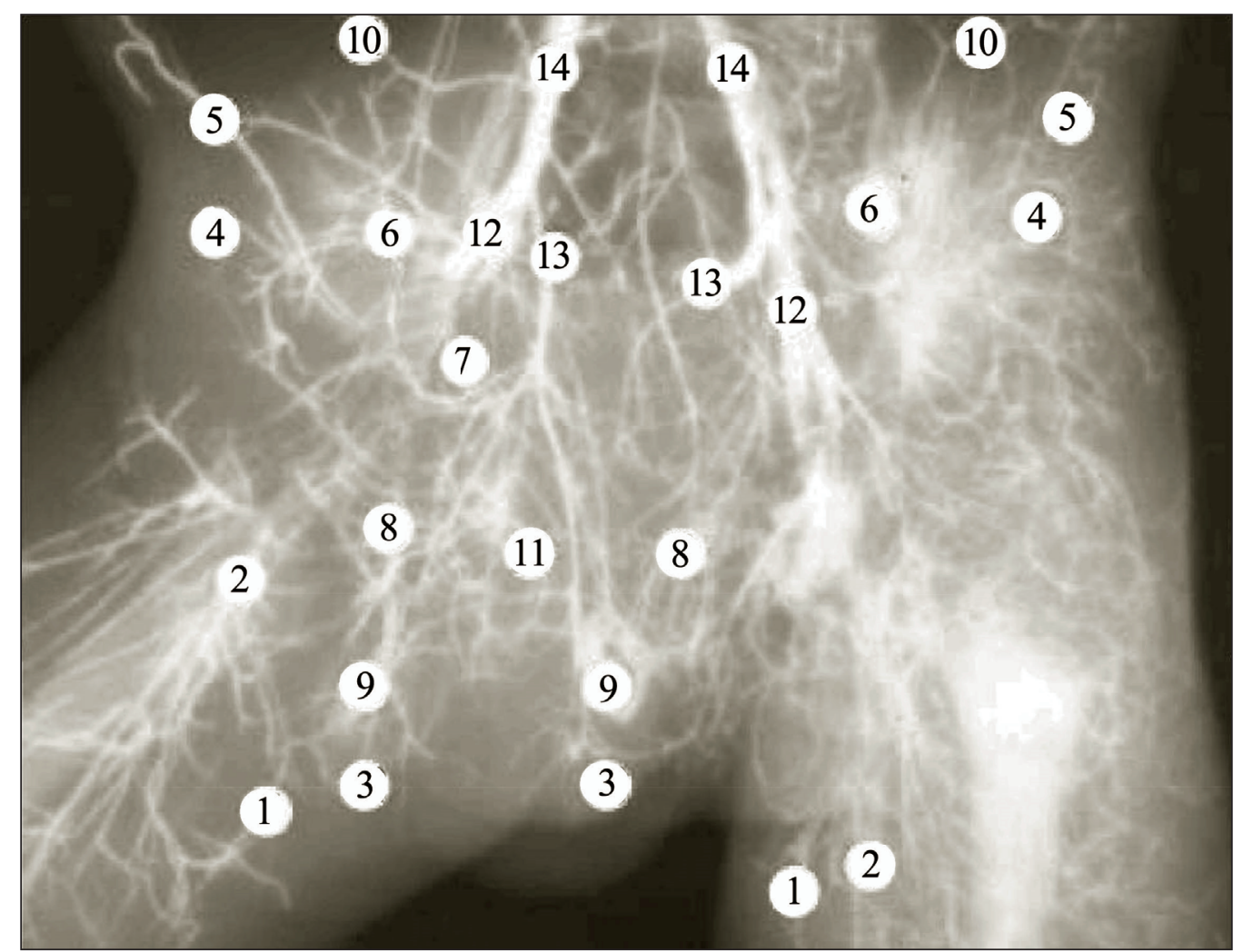

Fig. 7. X-ray of the pelvis and anterior femoral areas of the male fetus, $320.0 \mathrm{~mm}$ of PCL. The right thigh is withdrawn. Venous vessels are filled with a mixture of red lead oxide. Mag. 2.1x:

1 - great saphenous veins; 2 - femoral veins; 3 - skin scrotal veins; 4 - superficial circumflex iliac veins; 5 - deep circumflex iliac veins; 6 - testicular veins; 7 - vein of the right deferent duct; 8 - pampiniform plexus; 9 -intra-organ veins of the testicles and epididymis; 10 - anastomoses of the testicular veins with kidney capsular veins and peritoneum veins;

11 - venous plexus of the pelvis; 12 - external iliac veins; 13 - internal iliac veins; 14 - common iliac veins.

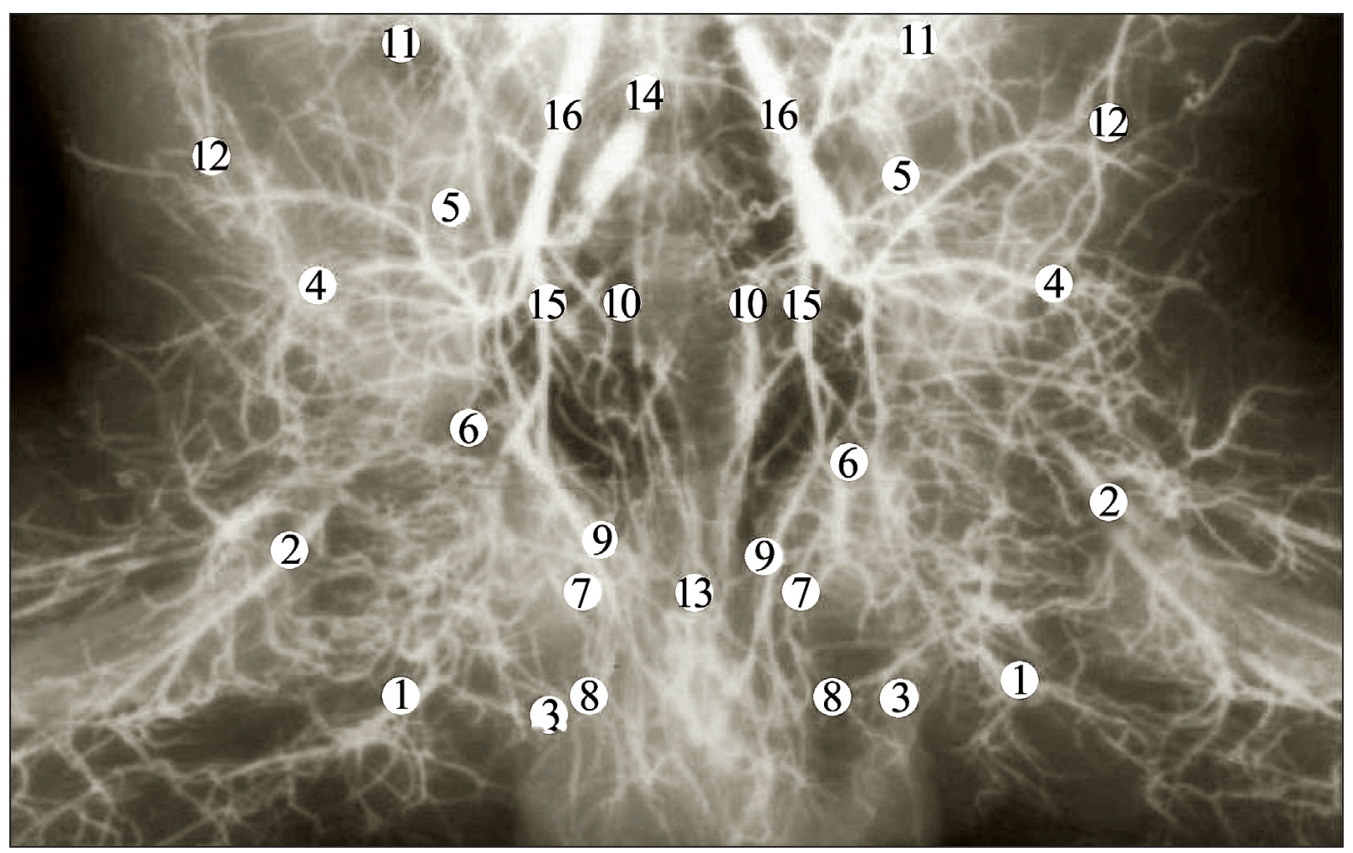

Fig. 8. X-ray of the pelvis, perineum and anterior femoral areas of the male fetus, $375.0 \mathrm{~mm}$ of PCL. Venous vessels are filled with a mixture of red lead oxide. Mag. $1,8^{\mathrm{x}}$ :

1 - great saphenous veins with branches; 2 - femoral veins; 3 - anastomosis between the anterior scrotal veins and the external pudendal veins; 4 - veins of the abdomen anterolateral wall; 5 - testicular veins; 6 - deferent duct;

7 - pampiniform plexus; 8 - venous plexus of the testicular elevator; 9 - internal pudendal veins; 10 -inferior epigastric veins 11 - peritoneal veins and kidney capsular veins; 12 - chest-epigastric veins; 13 - vesical and prostate gland venous plexus; 14 - umbilical vein; 15 - internal iliac veins; 16 - common iliac veins. 
not only of different age groups but also of the same age, requires the complete removal of the concept of 'norm'. Any deviation from the 'classic version' implies the risk of tactical errors in the surgical correction of pathological venous reflux. Clarification of the forms of GSV anatomical variability in human fetuses of 4-10 months expands the idea of fetal variant anatomy of the superficial veins of the lower extremities. Along with general patterns of the GSV structure and topography, their fetal anatomy is different for each specific fetus.

The predominance of transitional vein type (89 specimens, $55.6 \%$ ) over main (54 specimens, 33.8\% of cases) and loose ones (17 specimens, $10.6 \%$ of cases) is characteristic for the GSV. The main type prevails over the loose type in the ratio of 3.2:1. The coincidence of the type of GSV formation on the right and left lower extremities was observed in 49 studied fetuses (61.3\% of cases). No significant gender differences were found in the GSV typology.

The knowledge of GSV topography options is important for correct interpretation of phlebographic research data and individual choice of the most rational method of surgical intervention. The obtained data on anatomical variants of the GSV topography will allow surgeons to determine the volume of primary surgery for varicose disease and anatomically assess the possibility of relapses.

\section{Conclusions}

Human fetuses have anatomical variability of the great saphenous vein, which is characterized by variability in shape, topography, and bilateral asymmetry of its branches and anastomosis formation.

The anterior accessory saphenous vein was detected in $71.3 \%$ of the studied fetuses, while the posterior accessory saphenous vein was found in $38.1 \%$ of cases.

The great saphenous vein is characterized by the predominance of the transitional vein type $(55.6 \%$ of cases) over the main (33.8\% of cases) and loose (10.6\%o cases) ones. The main type prevails over the loose type in the ratio of 3.2:1. The coincidence of the type of formation of a great saphenous vein on the right and left lower extremities was observed in $61.3 \%$ of fetuses. Significant gender differences in the typology of the great saphenous vein in human fetuses were not found.

\section{Author Contributions:}

Conceptualization, T.K.; methodology, P.H. and V.D.; software, G.S.; validation, M.R.; formal analysis, T.K.; investigation, G.S.; resources,M.R.; data curation, T.K. and P.H.
; writing-original draft preparation,T.K.; writing-review and editing, P.H., T.K.; visualization, P.H.; supervision, P.H. and L.F.; project administration, P.H. All the authors have read and agreed with the final version of the article.

\section{Compliance with Ethics Requirements:}

„The authors declare no conflict of interest regarding this article"

"The authors declare that all the procedures and experiments of this study respect the ethical standards in the Helsinki Declaration of 1975, as revised in 2008(5), as well as the national law. Informed consent was obtained from all the patients involved in the study"

"No funding for this study"

\section{Acknowledgements: \\ None}

\section{References}

1. Chwała M, Szczeklik W, Szczeklik M, Aleksiejew-Kleszczyński T, Jagielska-Chwała M. Varicose veins of lower extremities, hemodynamics and treatment methods. Adv Clin Exp Med. 2015; 24(1): 5-14.

2. Jawień A, Grzela T, Ochwat A. Prevalence of chronic venous insufficiency (CVI) in men and women of Poland. Multicenter cross-sectional study of 40095 patients. Phlebology. 2003;18: 110-122.

3. Rabe E, Guex JJ, Puskas A, Scuderi A, Fernandez Quesada F; VCP Coordinators. Epidemiology of chronic venous disorders in geographically diverse populations: results from the Vein Consult Program. Int Angiol. 2012;31(2):105-15.

4. Michaels JA, Brazier JE, Campbell WB, MacIntyre JB, Palfreyman SJ, Ratcliffe J. Randomized clinical trial comparing surgery with conservative treatment for uncomplicated varicose veins. Br J Surg. 2006;93(2):175-81.

5. Marsden G, Perry M, Kelley K, Davies AH; Guideline Development Group. Diagnosis and management of varicose veins in the legs: summary of NICE guidance. BMJ. 2013;347:f4279.

6. Meissner MH. Lower extremity venous anatomy. Semin Intervent Radiol. 2005;22(3): 147-156.

7. Kim R, Lee W, Park EA, Yoo JY, Chung JW. Anatomic variations of lower extremity venous system in varicose vein patients: demonstration by three-dimensional CT venography. Acta Radiol. 2017; 58(5): 542-549.

8. Samadarsi R, Srijith PT, Santosh K. Complicated inguinoscrotal hernia management by endoscopic totally extraperitoneal mesh repair. IJSS Journal of Surgery. 2019; 5(3): 7-12.

9. Soo A, Noel D, MacGowan S. Ultrasound mapping of the long saphenous vein in coronary artery bypass graft surgery. Interact Cardiovasc Thorac Surg. 2013;16(6):886-887.

10. Chernyavskiy A, Volkov A, Lavrenyuk O, Terekhov I, Kareva Y. Comparative results of endoscopic and open methods of vein harvesting for coronary artery bypass grafting: a prospective randomized parallel-group trial. J Cardiothorac Surg. 2015;10:163.

11. Nazir SS, Khan M. Thrombosis of the dorsal vein of the penis (Mondor's Disease): A case report and review of the literature. Indian J Urol. 2010;26(3):431-433. 
12. Spinedi L, Broz P, Engelberger RP, Staub D, Uthoff H. Clinical and duplex ultrasound evaluation of lower extremities varicose veins - a practical guideline. Vasa. 2017;46(5):325-336.

13. Kumar N, Aithal AP, Swamy RS, Nayak SB, Rao MKG, Abhinitha P. Bifurcated great saphenous vein: a report on its therapeutic and diagnostic perspectives. J Cardiovasc Echogr. 2017; 27(3):107-109

14. Rao TR, Korkode R. Incidence of duplication of great saphenous vein in the thigh and its clinical significance - a case report. International Journal of Anatomical Variations. 2013;6:165-166. 